\title{
Development and characterization of two new cell lines from common carp, Cyprinus carpio (Linn)
}

\author{
Wazir S Lakra*, M Goswami, T Rajaswaminathan, Gaurav Rathore \\ Molecular Biology and Biotechnology Division - National Bureau of Fish Genetic Resources - Canal Ring Road, Dilkusha, Lucknow, 226002, India
}

\begin{abstract}
Two new cell lines (CCF and CCH) were established from fin and heart tissues of common carp, Cyprinus carpio. The cells were optimally maintained in Leibovitz-15 medium supplemented with $10 \%$ fetal bovine serum (FBS) and $10 \mathrm{ng} / \mathrm{m} 1 \mathrm{of}$ basic fibroblastic growth factor (bFGF). The effects of temperature, concentration of FBS and bFGF on the growth of CCF and CCH cells were examined. The temperature ranged from 24 to $32{ }^{\circ} \mathrm{C}$ for good growth of the cells. The growth rate of cells was higher in medium containing $10 \%$ FBS and the addition of bFGF to the medium significantly increased the growth rate. The CCF cells were found to be epithelial, while the $\mathrm{CCH}$ cells were fibroblastic in nature. The cytogenetic analysis of the cell lines revealed a diploid number of 100 chromosomes in $\mathrm{C}$. carpio. The viability of CCF and CCH cell lines were 70 and $72 \%$, respectively, after six months of storage in liquid nitrogen (-196 $\left.{ }^{0} \mathrm{C}\right)$. Molecular characterization of the cell lines using $16 \mathrm{~S}$ rRNA and Cytochrome Oxidase Subunit I (COI) revealed the origin of the cell lines. These new cell lines will be useful for isolation of fish viruses and other in vitro biotechnological studies
\end{abstract}

Key terms: Cyprinus carpio, cell line, mtDNA.

\section{INTRODUCTION}

Cyprinus carpio, commonly called common carp, is a widely distributed freshwater fish and a natural inhabitant of riverine systems of Asia and Eastern Europe. The species entered the carp polyculture system in India in the late 1950s and thereafter the species has become an integral part of the composite fish culture system in the country. The adoption of intensive farming practices, unregulated use of inputs and inbreeding in hatcheries, has led to increased disease incidence in tropical carp. There have been several incidences of mass mortality of carp in culture systems, which are suspected to be caused by microbial diseases, particularly of viral aetiology (Mohan and Shankar, 1994). Hence, development of a cell line from tropical fish species for identifying pathogenesis of viral diseases and for vaccine production against viral and bacterial diseases is necessary.

Most cell lines in the past have been developed from temperate fish (Fryer and Lannon, 1994), except primary cultures from the kidney of the stinging catfish Heteropneustes fossilis (Singh et al., 1995), caudal fin of $L$. rohita (Lakra and Bhonde, 1996), heart tissues of Indian major carp (Rao et al., 1997), caudal fin of Tor putitora (Prassana et al., 2000), ovary of Clarias gariepinus (Kumar et al., 2001), gill of C. gariepinus (Rathore et al., 2001) and liver and kidney of L. rohita (Lakra et al., 2005). The development of new cell lines from Tor putitora (Lakra et al., 2006a), Lates calcarifer (Lakra et al., 2006b; Parameswaran et al., 2006 and 2007), Epinephelus coioides and Chanos chanos (Parameswaran et al., 2007) in recent years have opened new vistas for fish tissue culture research on tropical aquatic species.

Although viral infections in fish in India are likely to exist, no virus has been isolated and characterized so far (Lakra et al., 2006). The carp leucocyte cell line (CLC; Weyts et al., 1997) and epithelioma papulosum cyprini cell lines (EPC; Fijan et al., 1983) have been developed from the common carp. Development of cell lines from various tissues of common carp is desirable for developing cell models for in vitro study of their cellular physiology, molecular biology, genetics, immunology, endocrinology, nutrition, comparative biology and biotechnology (Ye et al., 2006).

The present study reports two new cell lines (CCF and $\mathrm{CCH}$ ) from fin and heart tissues of $C$. carpio and their evaluation for optimal growth conditions and molecular and cytogenetic characterization.

\section{METHODS}

Primary cell culture

Healthy juveniles of $C$. carpio (body weight: 50-60 gm and body length: $20-25 \mathrm{~cm}$ ) were obtained from commercial hatcheries in Uttar Pradesh and maintained in the wet lab of the institute. All fish specimens were euthanized by keeping them on ice for more than $15 \mathrm{~min}$ and surface sterilized by dipping in an iodophore (Betadine, Pharmabutor, India) for 5 min. Primary cell cultures were initiated by aseptically collecting fin, heart and swim bladder tissues. The tissues were transferred to phosphate buffered saline (PBS) (Invitrogen), containing antibiotic and antimycotic solution (1000 U penicillin, $1000 \mu \mathrm{g}$ streptomycin and $25 \mu \mathrm{g}$ amphotericin B per $\mathrm{ml}$ ) (Invitrogen). The tissue samples were then minced with sterile dissecting blades and scissors at room temperature and washed four times with PBS containing antibiotic and antimycotic solution. Approximately 25 tissue fragments ( 1 to $2 \mathrm{~mm}^{3}$ ) were individually explanted into 25 $\mathrm{cm}^{2}$ tissue culture flasks (Nunc, Denmark) in $50 \mu \mathrm{l}$ of fetal bovine serum (FBS) (Invitrogen). After allowing the tissue to attach for $8 \mathrm{~h}$ at room temperature, $5 \mathrm{ml}$ of Leibovitz-15 medium (L-15) containing 20\% FBS and $10 \mathrm{ng} / \mathrm{ml}$ basic fibroblastic growth factor (bFGF) was added to each flask. The flasks were incubated at $28^{\circ} \mathrm{C}$ and the medium was replaced

\footnotetext{
* Corresponding Author: Wazir S Lakra. Director, National Bureau of Fish Genetic Resources, Canal Ring Road, Dilkusha, Lucknow, 226002, India E-mail:wslakra@gmail.com Phone: +91-522-2442441. Fax: +91-522-2442403 
every five days. The flasks were observed daily for attachment, spreading, proliferation and morphological details using an inverted microscope (Olympus Optical Co., Ltd) equipped with phase optics.

Subculture

After reaching $95 \%$ confluency, the cells were trypsinized using $0.25 \%$ trypsin solution and $0.2 \%$ ethylenediaminetetraacetic acid (EDTA) in PBS. The subcultured cells were grown in fresh L-15 with 15\% FBS. In the initial 10 subcultures, $50 \%$ of the culture medium was replaced with the fresh medium. The concentration of FBS in the L-15 medium was reduced to $10 \%$ for further subculturing.

Growth studies

Growth characteristics of the cell lines were assessed at selected temperatures, FBS and bFGF concentrations in L-15 media. The growth rates were assessed at 5 incubation temperatures $\left(18,20,24,28\right.$ and $\left.32{ }^{\circ} \mathrm{C}\right)$ for 7 days. A seeding concentration of $2 \times 10^{5}$ cells $/ \mathrm{ml}$ at 45 passage was used in 25 $\mathrm{cm}^{2}$ tissue culture flasks. On alternate days, 3 flasks from different temperatures at which they were incubated were withdrawn, trypsinized and cells were counted (4 counts per flask) using a hemocytometer. Analogous procedures were performed for the effects of various concentrations of FBS (5, $10,15$ and $20 \%$ ) and bFGF (0, 5 and $10 \mathrm{ng} / \mathrm{ml})$ on cell growth at $28^{\circ} \mathrm{C}$ for 7 days.

\section{Cryopreservation}

The ability of cells to survive in liquid nitrogen $\left(\mathrm{LN}_{2}\right)$ at -196 ${ }^{0} \mathrm{C}$ and their stability were assessed in three replicates in freezing medium using previously described methods (Freshney, 1994). Cells growing logarithmically for CCF and $\mathrm{CCH}$ at 47 and 48 passages, respectively, were harvested by centrifugation and washed with PBS and then suspended in recovery medium (Invitrogen) at $1 \times 10^{6}$ cells per $\mathrm{ml}$. Aliquots $(1.0 \mathrm{ml})$ were dispensed into $2.0 \mathrm{ml}$ sterile cryovials (10 numbers) (Nunc) held at $4{ }^{\circ} \mathrm{C}$ for $2 \mathrm{~h},-20{ }^{\circ} \mathrm{C}$ for $1 \mathrm{~h}$, at -70 ${ }^{\circ} \mathrm{C}$ overnight and then transferred into $\mathrm{LN}_{2}$. The frozen cells were recovered after 6 months of post-storage by thawing at $37{ }^{\circ} \mathrm{C}$ in a water bath. Following removal of the freezing medium by centrifugation, cells were suspended in L-15 with $10 \%$ FBS. The viability of the cells was measured by trypan blue staining and the number of cells was counted using a haemocytometer. The viable cells were seeded into $25 \mathrm{~cm}^{2}$ tissue culture flasks for further subculturing.

Karyotyping

Chromosomal counts were established at passage 47 and 48 for fin and heart cells, respectively. Cells were seeded in duplicate $75 \mathrm{~cm}^{2}$ tissue culture flasks in L-15 medium with $10 \%$ FBS. After $24 \mathrm{~h}$ incubation, spent medium was replaced with $10 \mathrm{ml}$ of fresh medium containing $0.1 \mathrm{ml}$ colcemid solution (1 $\mu \mathrm{g} \mathrm{ml} / 1)$, (Sigma, St Louis, MO, USA) into the 1day-old cell culture for $2 \mathrm{~h}$ at $28{ }^{\circ} \mathrm{C}$. After harvesting by centrifugation $(70 \mathrm{~g}, 5 \mathrm{~min})$, the cells were suspended in a hypotonic solution consisting of $0.5 \% \mathrm{KCl}$ for $10 \mathrm{~min}$ and fixed in methanol: acetic acid (3:1). The slides were prepared following the conventional drop-splash technique (Freshney, 1994). The chromosomes were counted under a microscope (Leica, Germany), after staining with 5\% Giemsa for $10 \mathrm{~min}$.

Molecular characterization (16S rRNA and COI mtDNA genes)

\section{DNA Isolation}

DNA extractions from CCF and CCH cells at passage 47 and 48 respectively, were completed following Ruzzante et al. (1996) with minor modifications. Briefly, samples were homogenized separately in incubation buffer $(10 \mathrm{mM}$ Tris$\mathrm{HCl}$ and $10 \mathrm{mM}$ ethylenediaminetetraacetic acid (EDTA), pH8.0), centrifuged at $10000 \mathrm{rpm}$ at $4{ }^{\circ} \mathrm{C}$ after which the supernatants were digested with lysis buffer (10mM Tris$\mathrm{HCl}, 10 \mathrm{mM}$ ethylenediaminetetraacetic acid (EDTA), pH8.0, $0.5 \%$ SDS and $50 \mu \mathrm{g} / \mathrm{ml}$ Proteinase K). After incubation at 37 ${ }^{\circ} \mathrm{C}$ for overnight, the digests were deproteinized by successive phenol / chloroform and iso-amyl alcohol extraction and DNA was recovered by ethanol precipitation, drying and resuspension in TE buffer. The concentration of isolated DNA was estimated at wavelength of $260 \mathrm{~nm}$ using a UV spectrophotometer. The DNA was diluted to get a final

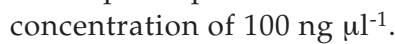

\section{Amplification and Sequencing}

The 551 bp fragment of mitochondrial 16S rRNA gene was amplified in a $50 \mu$ l reaction volume with $5 \mu \mathrm{l}$ of $10 \mathrm{X}$ Taq polymerase buffer, $0.2 \mathrm{mM}$ of each dNTP, $0.4 \mu \mathrm{M}$ of each primer, $2.5 \mathrm{U}$ of Taq polymerase and $5 \mu$ l genomic DNA using the thermal cycler PTC 200 (MJ Research). The primers used for the amplification of the partial 16S rRNA gene were 16SAR (5'-CGCCTGTTTATCAAAAACAT-3') and 16SBR (5'- CCGGTCTGAACTCAGATCACGT -3') (Palumbi et al. 1991). The thermal profile used was 36 repetitions of a threestep cycle consisting of denaturation at $94{ }^{\circ} \mathrm{C}$ for 1 minute, annealing at $55^{\circ} \mathrm{C}$ for 1 minute and extension at $72{ }^{\circ} \mathrm{C}$ for 1.5 minutes, including 4 minutes for initial denaturation at $94{ }^{\circ} \mathrm{C}$ and 7 minutes for the final extension at $72{ }^{\circ} \mathrm{C}$.

The $655 \mathrm{bp}$ fragments of cytochrome oxidase subunit I (COI) were also amplified in a final concentration of $50 \mu 1$ volume with a final concentration of $5 \mu \mathrm{l}$ of $10 \mathrm{X}$ Taq polymerase buffer, $2 \mu \mathrm{l}$ of $\mathrm{MgCl}_{2}(50 \mathrm{mM}), 0.25 \mu \mathrm{l}$ of each dNTP $(0.05 \mathrm{mM}), 0.5 \mu \mathrm{l}$ of each primer $(0.01 \mathrm{mM}), 0.6 \mathrm{U}$ of Taq polymerase and $5 \mu \mathrm{l}$ of genomic DNA. The primers used for the amplification of the COI gene were FISHF15'TCAACCAACCACAAAGACATTGGCAC ${ }^{\prime}$ ' and FISHR15'TAGACTTCTGGGTGGCCAAAGAATCA3' (Ward et al., 2005). The thermal regime consisted of an initial step of 2 minutes at $95^{\circ} \mathrm{C}$ followed by 35 cycles of 40 seconds at $94{ }^{\circ} \mathrm{C}$, 40 seconds at $54{ }^{\circ} \mathrm{C}$ and 1 minute 10 seconds at $72{ }^{\circ} \mathrm{C}$ followed by final extension of 10 minutes at $72{ }^{\circ} \mathrm{C}$.

The PCR products were visualized on $1.2 \%$ agarose gels and the most intense products were selected for sequencing. Products were labeled using the BigDye Terminator V.3.1 Cycle sequencing Kit (Applied Biosystems, Inc) and sequenced bidirectionally using an ABI 3730 capillary sequencer following manufacturer's instructions. The obtained sequences of PCR fragments were compared to the known sequences of the species. 


\section{Statistical Analysis}

Data were expressed as mean \pm S.E. A value of $\mathrm{P}<0.05$ was considered as statistically significant. The statistical analysis was computed using SPSS software.

\section{RESULTS}

The radiation of cells from the explants started after 2 to 3 days in $25 \mathrm{~cm}^{2}$ tissue culture flasks for CCF and $\mathrm{CCH}$ and a monolayer of cells was formed approximately 3 weeks after the implantation. The morphology of common carp fin cells (CCF) was fibroblastic and epithelial during their initial growth, which changed to epithelial-like cells gradually (Fig. $1)$. In contrast, the common carp heart $(\mathrm{CCH})$ cells were basically fibroblastic and myoctyes in the primary culture. However, the cells became uniformly fibroblastic in later passages. The CCF cells were subcultured successfully 49 times, whereas $\mathrm{CCH}$ cells were subcultured 51 times. The cells were subcultured on 9-day intervals in L-15 medium with $20 \%$ FBS for the first 10 subcultures, at 5-day intervals in L-15 with $10 \%$ FBS during the subsequent passages.

The CCF and CCH cells exhibited different growth pattern at different temperatures (Fig. 2 A). The growth of cells increased as the culture temperature increased, when the temperature was between 20 and $28{ }^{\circ} \mathrm{C}$. Although cells grew well at $28{ }^{\circ} \mathrm{C}$, the growth rate of cells cultured at $32{ }^{\circ} \mathrm{C}$ began to decrease. The growth rate was less markedly at $18^{\circ} \mathrm{C}$.

The effect of FBS and bFGF concentration on the proliferation of cells is shown in Fig. $2 \mathrm{~B}$ and Fig. $2 \mathrm{C}$. The growth rate of cells in medium containing $20 \%$ FBS was higher than that of cells in medium containing 5-15\% FBS.
The addition of $10 \mathrm{ng} / \mathrm{ml} \mathrm{bFGF}$ stimulated the proliferation of cells. The absence of bFGF significantly decreased the proliferation of cells.

Evaluation of the viability of $\mathrm{CCF}$ and $\mathrm{CCH}$ cells stored in liquid nitrogen $\left(-196^{\circ} \mathrm{C}\right)$ established the capability of the cells to survive following 6 month of storage. More than 70 and $72 \%$ of CCF and $\mathrm{CCH}$ cells from each vial remained viable after the storage period and retained the ability to attach and grow at $28^{\circ} \mathrm{C}$. Following storage, no obvious alterations in morphology or growth pattern were observed for cells.

The CCF and CCH cell lines had similar chromosome morphology. The results of chromosome counts of 82 metaphase plates revealed that the diploid number of chromosomes in CCF and CCH cells ranged from 46 to 121 and 47 to 126, respectively (Fig. 3 A \& B). Both heteroploidy and aneuploidy were observed in the two cell lines, although they were small in proportion. Nevertheless, the modal diploid number of chromosomes for all the cell lines was found to be 100 .

An analysis of mitochondrial 16S rRNA and COI genes was performed to verify the origin of the two cell lines. Amplification from the 16S rRNA and COI genes for all cell lines revealed the expected PCR products of $551 \mathrm{bp}$ and 655 bp, respectively (Fig. 4). Subsequent comparative analysis of the identified sequences demonstrated a $99 \%$ to $100 \%$ match for $16 \mathrm{~S}$ rRNA and COI region of the known mitochondrial DNA sequences from C. carpio. GenBank Accession No. for 16S rRNA and COI of CCF and $\mathrm{CCH}$ cell lines were FJ183814-FJ183815 and FJ183806 - FJ183807 respectively. Our data demonstrated that $\mathrm{CCF}$ and $\mathrm{CCH}$ cell lines are indeed truly derived from C. carpio.
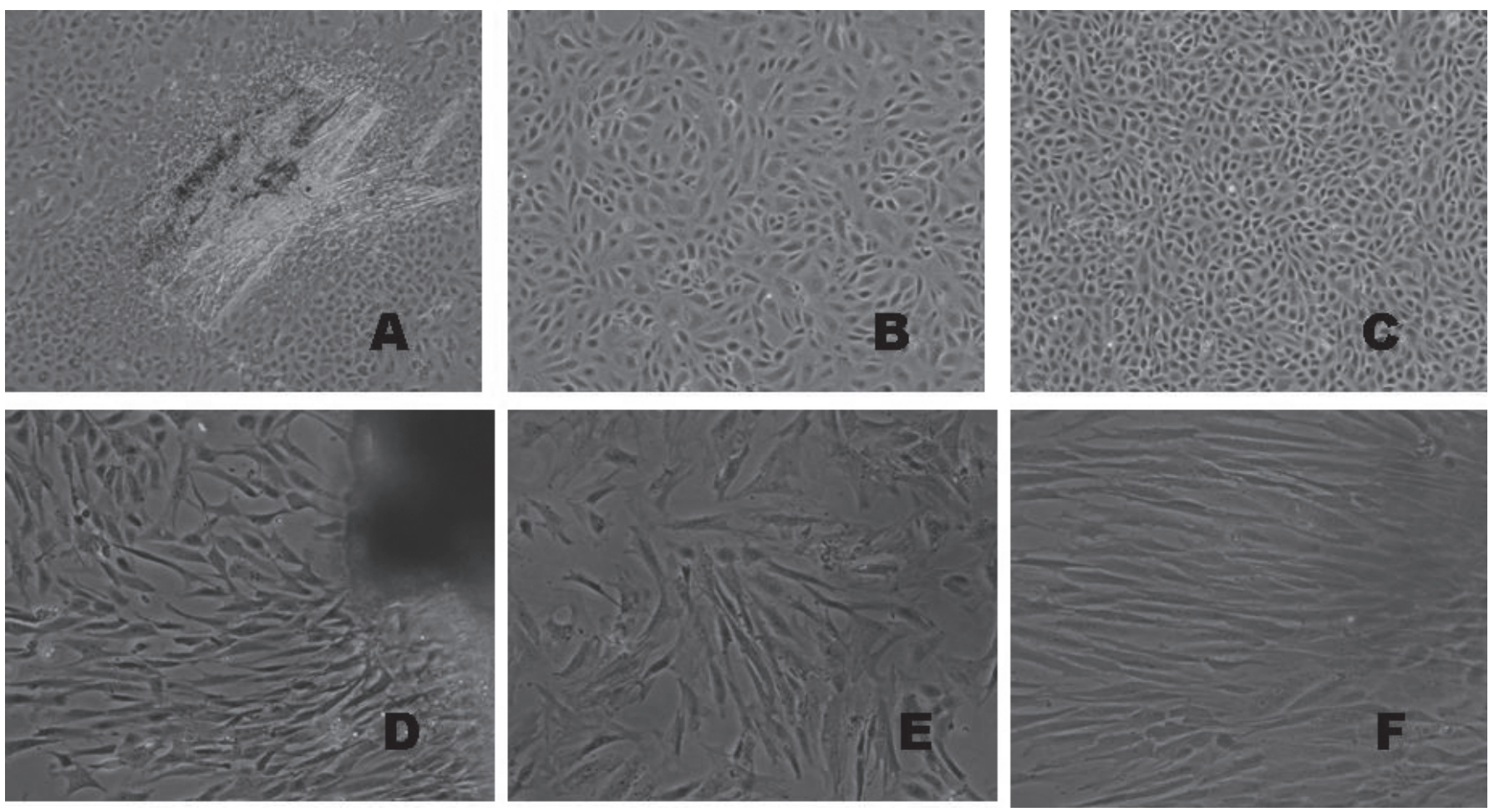

Fig. 1: Phase contrast microscope of common carp cells derived from $(A, B, C)$ fin and $(D, E, F)$ heart (200X).

$A \& D)$ Explant showing radiation of cells after 3 days from fin and heart, respectively.

$B$ \& E) subcultured cells of fin and heart, respectively, at $10^{\text {th }}$ passage

$C \& F)$ subcultured cells of fin and heart, respectively, at $30^{\text {th }}$ passage 
Growth of CCF at different temperatures ("C)

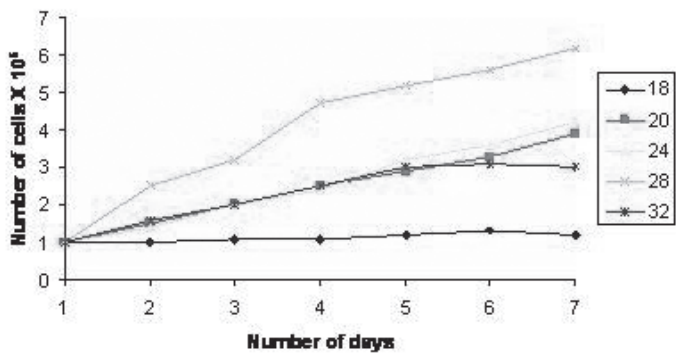

Growth of $\mathrm{CCH}$ at different temperatures $\left({ }^{\circ} \mathrm{C}\right)$

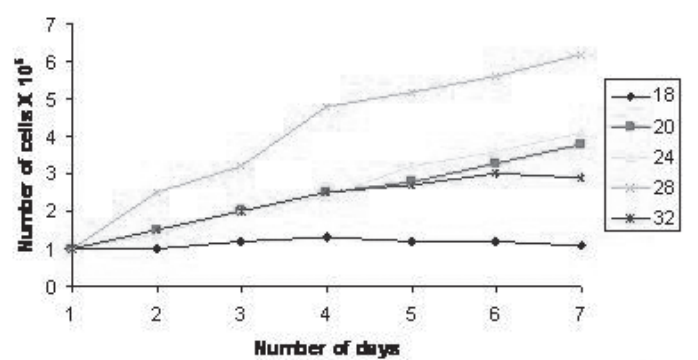

Growth of cells of Cyprinus carpio at different te mperature $\left({ }^{\circ} \mathrm{C}\right)$

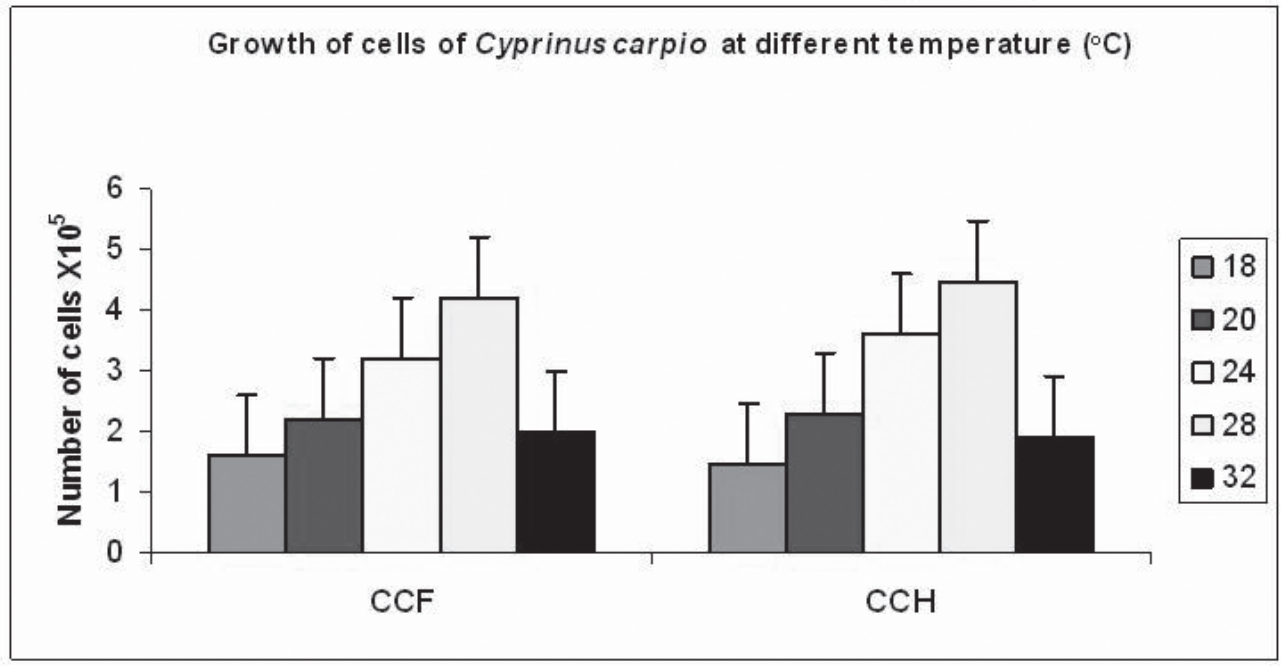

$\mathrm{CCH}$

Fig. 2A

Growth of CCF at different concentration of FBS (percentage)

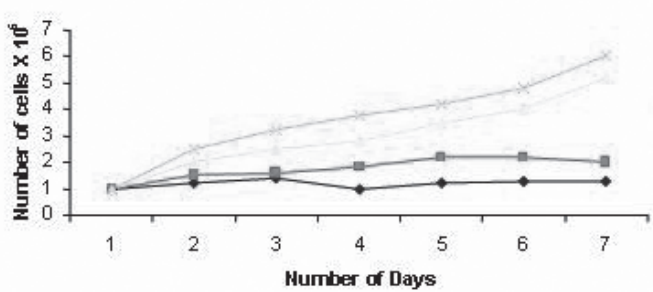

Growth of $\mathrm{CCH}$ at different concentration of FBS (percentage)

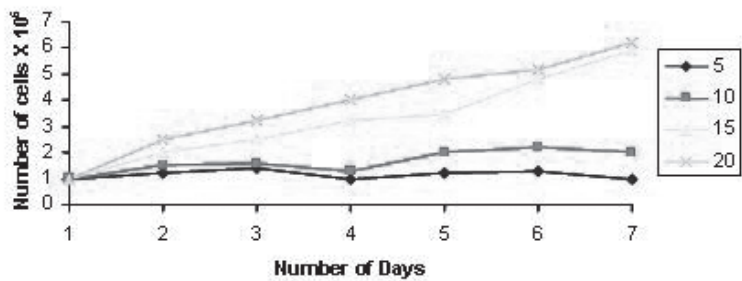

Fig. 2B

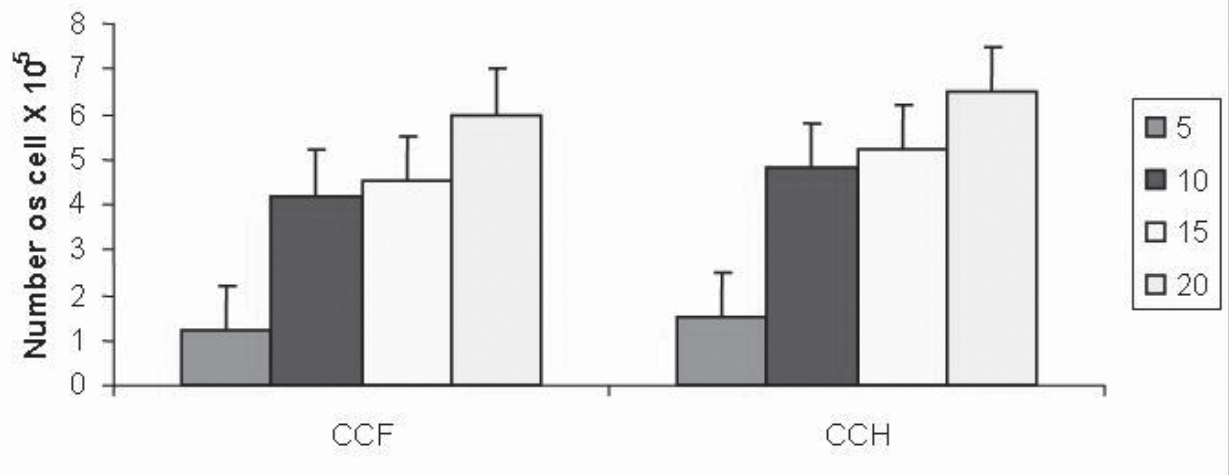



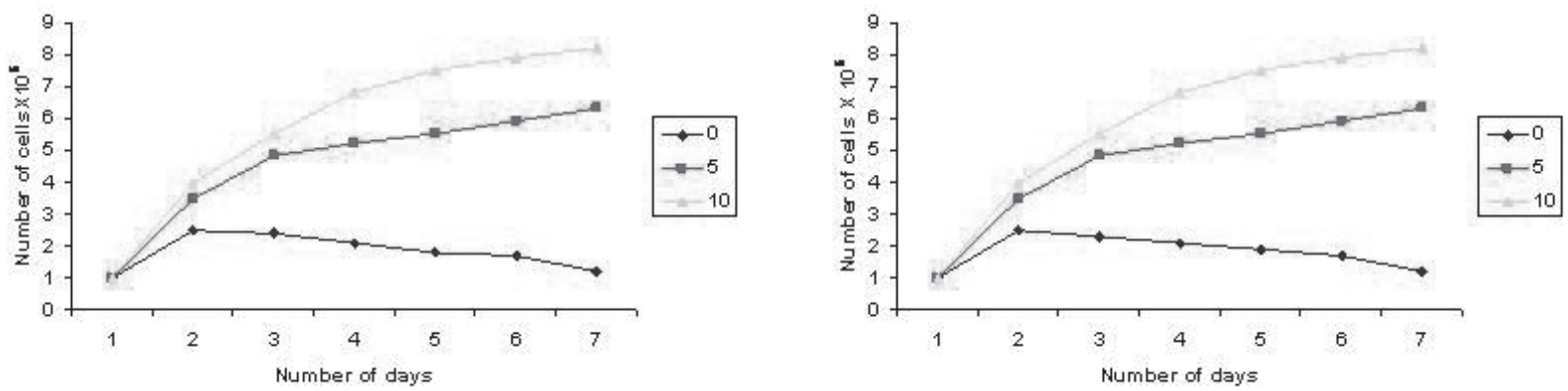

Fig. 2C

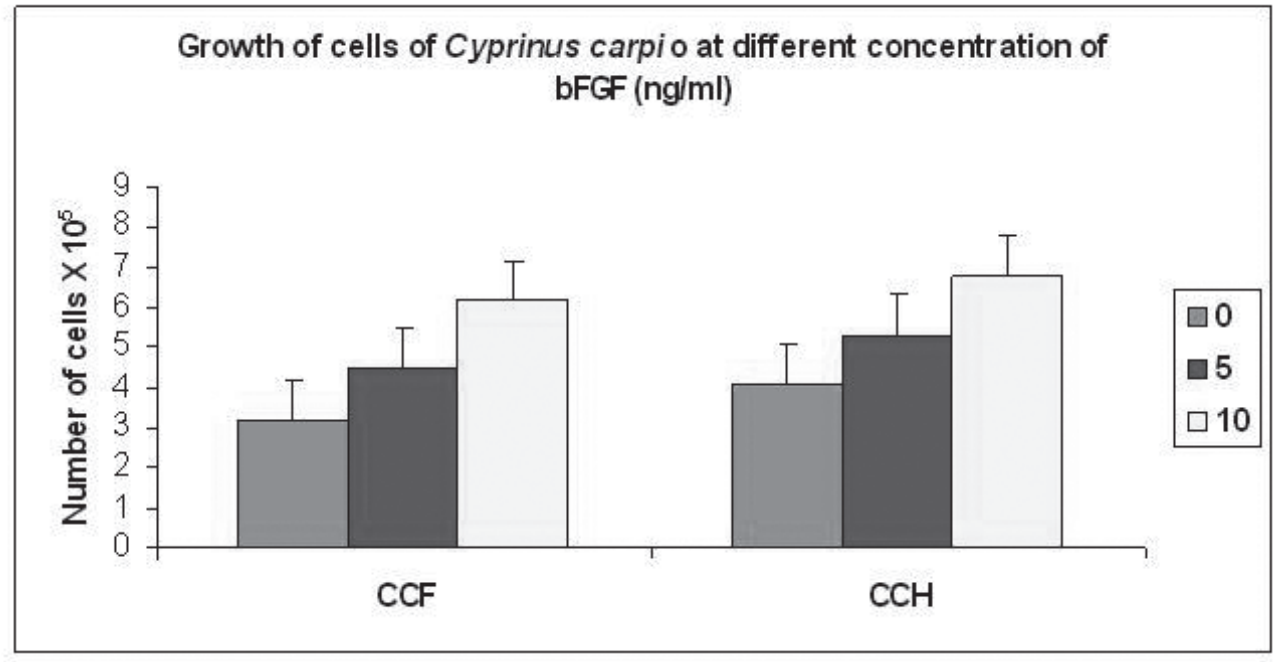

Fig. 2: In vitro growth curves of $\mathrm{CCF}$ and $\mathrm{CCH}$ cells of Cyprinus carpio at (A) Temperatures (18, 20, 24, 28 and $32^{\circ} \mathrm{C}$, (B) selected concentration of FBS $(5,10,15$ and $20 \%$ and $(C)$ bFGF $(0,5$ and $10 \mathrm{ng} / \mathrm{ml})$. Values were significantly different $(\mathrm{p}<0.05)$. Values are means \pm S.E. $(n=3)$.

\section{DISCUSSION}

Fish cell cultures are good models for in vitro studies of the propagation of pathogenic fish viruses. They also play important role in toxicological and functional genomics studies in fish. However, presently very few fish cell lines are available for research in tropical species. In the present research, in vitro cell culture systems from fin and heart of common carp, namely CCF and CCH cell lines, were established by the explant technique. The tissue of choice and optimum physico-chemical environment-like culture medium, FBS concentration, growth supplements, incubation temperature, etc. varies considerably across fish species. Joseph et al. (1998) observed good attachment and growth with caudal peduncle of Cirrhinus mrigala and heart tissues of C. mrigala and Catla catla. In primary culture of CCF, fibroblastic cells and epithelial cells coexisted. However, in subsequent subcultures, the epithelial like cells proliferated more rapidly than the fibroblastic cells and ultimately predominated. The pattern in $\mathrm{CCH}$ cells was fibroblastic and myoctyic, but fibroblastic cells were dominant after subsequent passage. Most of the primary cultures reported from fish in India were comprised of fibroblastic cells (Singh et al., 1995; Lakra \& Bhonde1996). A predominance of fibroblastic cells over epithelioid cells in cell cultures from fish has been reported by several workers in the past (Bejar et al., 1997; Chi et al., 1999).

Both CCF and $\mathrm{CCH}$ cells exhibited maximum growth rate at $28{ }^{\circ} \mathrm{C}$, but were growing over a wide temperature range $\left(20-32{ }^{\circ} \mathrm{C}\right)$. This property increases the spectrum of viruses that the cells can be used to isolate. The highest growth rate of various tropical fish cell lines was observed at $32{ }^{\circ} \mathrm{C}$ (Lai et al. 2003), $28{ }^{\circ} \mathrm{C}$ (Sathe et al., 1995) and 20-25 ${ }^{\circ} \mathrm{C}$ (Tong et al., 1997). A temperature of $35-37^{\circ} \mathrm{C}$ has been reported to be lethal to many fish cells (Tong et al., 1997).

The FBS is essential for survival and optimal growth of cells. In primary cell cultures, FBS at high concentrations $(20 \%)$ is favourable for cell growth and attachment. After subculture, the replication rate of CCF and $\mathrm{CCH}$ cells increased as the FBS concentration increased from 5 to $20 \%$. These observations are similar to those previously reported on the establishment of cell lines from other marine fish (Kang et al., 2003; Lai et al., 2003). However, concentration of FBS at $10 \%$ provided relatively good growth and this is an advantage to maintain the cell line at low cost.

Most cells do not survive or exhibit optimal phenotypic properties for any length of time when cultured in basal medium alone. The medium needs to be supplemented with additional growth and survival factors, such as hormones, transport proteins, trace elements or ECM (Extra Cellular 
Matrix) factors (Ham and McKeehan, 1979). The growth factors like bFGF, a potent mitogenic agent for human melanocytes has been used in previous studies (Halaban et al., 1998). The bFGF is a potent mitogen for embryonic stem cells derived from medaka Oryzias latipes (Hong and Schartl, 1996) and sea perch (Chen et al., 2003). Our results demonstrate that bFGF stimulates proliferation of CCF and $\mathrm{CCH}$ cells and can be used as growth factor in other cell cultures also.

The euploid cell condition is an important parameter for characterizing a cell line. The results of chromosome counts of 82 metaphase plates from cell line at passage 47 and 48 revealed that the chromosome numbers of $\mathrm{CCF}$ and $\mathrm{CCH}$ varied from 46 to 121 and 47 to 126, respectively. Nevertheless, the modal number of chromosomes was 100 . Karyotype analysis revealed that over $48 \%$ and $46 \%$ of the CCF and CCH cells possessed a diploid chromosome number of $2 n=100$, respectively, which is identical to the modal chromosome number of common carp reported earlier (Ohno et al., 1967). This diploid rate is similar to or higher than other reports in other fish cell lines (Sun et al., 1995, Hong et al., 1996, Chen et al., 2003).

To confirm that the cell lines originated from common carp, amplifications of $551 \mathrm{bp}$ and $655 \mathrm{bp}$ fragments of $16 \mathrm{~S}$ rRNA and COI gene sequences for all cell lines were performed. The sequence analysis of both $16 \mathrm{~S}$ rRNA and COI fragments showed $99 \%$ to $100 \%$ similarity with respective gene fragment of $C$. carpio. The results indicated that the two cell lines were of $C$. carpio. Species identification of cell lines is crucial for scientific research accuracy and reproducibility. Hebert et al. (2003) have demonstrated the utility of the COI gene as a universal barcode, referred to as "DNA barcodes" for the genetic identification of animal life. Recently, Cooper et al. (2007) used the COI region for identification of sixtyseven cell lines used for barcode analysis. Our analysis also proves the utility of the COI gene for identification of the newly established cell lines from $C$. carpio.

Cryopreservation of cell lines is necessary for long-term storage. The feasibility of cryopreservation of these two cell lines was demonstrated, with appreciable recovery after thawing of up to $72 \%$. It was $50 \%$ for SAF-1 (gilt-head sea bream) (Bejar et al., 1997), 73\% for GF-1 (grouper) (Chi et al., 1999) and 80-85\% for SF (Asian sea bass) (Chang et al., 2001).

Some pathogenic viruses are known to be organ- and tissue-specific, which makes the establishment of additional cell lines from different organs and tissues of a host species essential for proper monitoring of viral diseases. Therefore, the established common carp cell lines, CCF and $\mathrm{CCH}$ from fin and heart, respectively, would provide an enhanced capability for viral detection and identification in the aquatic animal species in India. These newly established and characterized cell lines from C. carpio will be disseminated / distributed to researchers all over the world on request for further research in fish biotechnology.
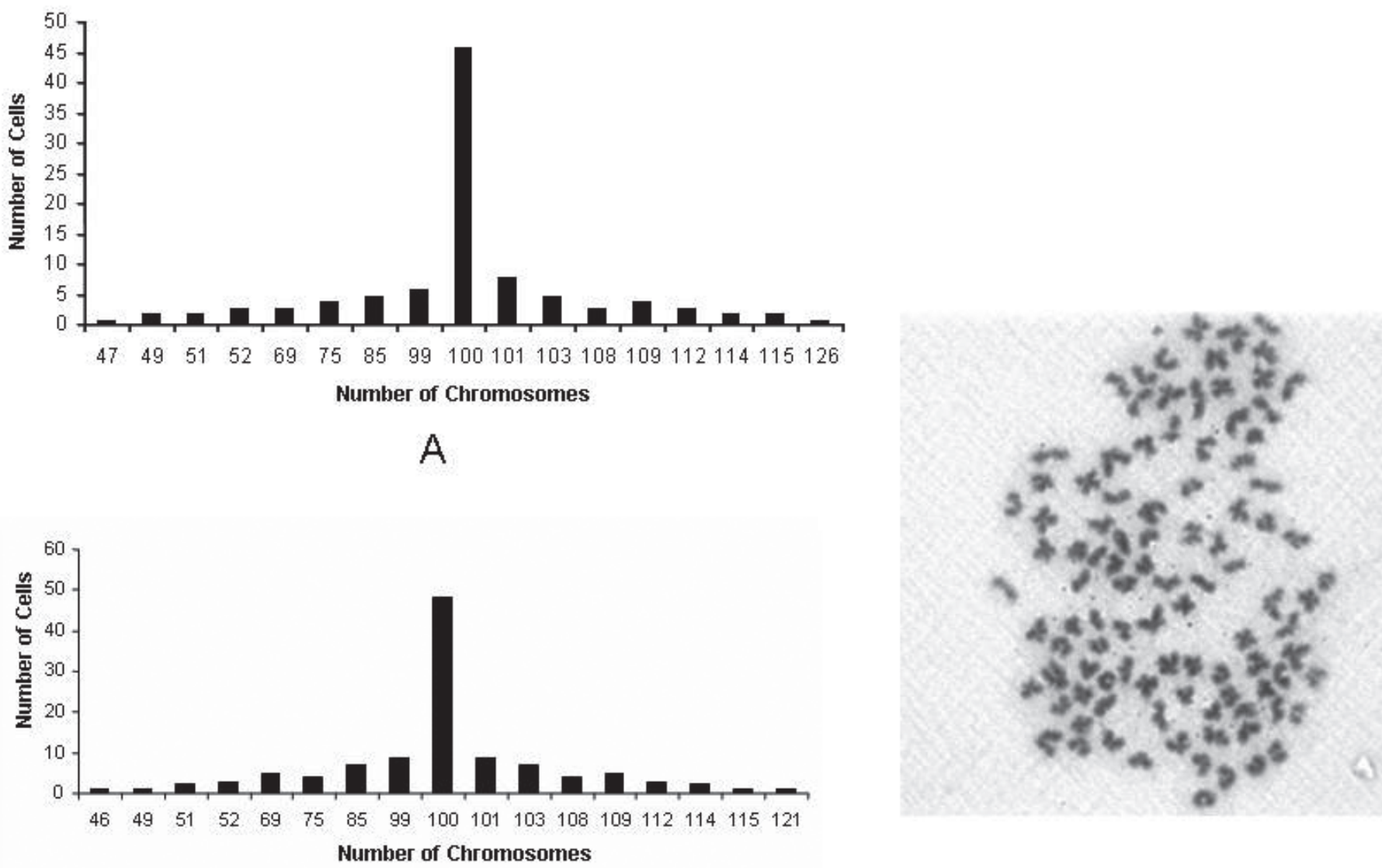

B

Fig. 3: A chromosome spread of $C$. carpio from cell lines (A) CCF and (B) $\mathrm{CCH}$ 




Fig. 4: PCR amplification of $655 \mathrm{bp}$ and $551 \mathrm{bp}$ fragment of the common carp genome using oligonucleotide primers from the conserved portions of $\mathrm{COI}$ and 16S rRNA region. Lane.1. Generuler express DNA ladder (Fermentas); Lane.2. COI negative control; Lane.3. Positive control COI; lane 4. CCH COI; Lane 5. CCF COI; Lane 6. 16S rRNA negative control; Lane 7. 16S rRNA positive control; Lane 8. CCH 16S rRNA; Lane.9. CCF 16S rRNA; Lane.10. Generuler express DNA ladder (Fermentas). (Negative Control: Without template; Positive Control: Muscle tissue of C. carpio).

\section{ACKNOWLEDGMENTS}

The authors are thankful to Dr S. Ayyappan, Director General, ICAR for his encouragement and the use of facilities.

\section{REFERENCES}

BEJAR J, BORREGO JJ, ALVAREZ MC (1997) A continuous cell line from the cultured marine fish gilt-head sea bream Sparus aurata (L.). Aquaculture150:143-153.

CHANG' SF, NGOH GH, KUEH LFS, QIN QW, CHEN CL, LAM TJ, SIN YM (2001) Development of a tropical marine fish cell line from Asian seabass (Lates calcarifer) for virus isolation. Aquaculture 192 (2-4):133145 .

CHEN SL, SHA ZX, YE HQ (2003) Establishment of a pluripotent embryonic cell line from sea perch (Lateolabrax japonicus). Aquaculture 218:141-151.

CHI SC, LO BJ, LIN SC (2001) Characterization of grouper nervous necrosis virus (GNNV). J. Fish Diseases 24 (1): 3-13.

COOPER, JK. SYKES G, KING S (2007) Species identification in cell culture: a two-pronged molecular approach. In Vitro Cell Dev. Biol Animal 43: 344-351.

FIJAN N, SULIMANOVIC D, BEARZOTTI M M, MUZINIC D, ZWILLENBERG L O, CHILMONCZYK S, VAUTHEROT JF, DE KINKELIN P (1983) Some properties of the epithelioma papulosum cyprini (EPC) cell line from carp Cyprinus carpio. Annales de d'Institut Pasteur. Virology 137: 207-220.

FRESHNEY RI (1994) Culture of Animal Cells: A Manual of Basic Technique. New York:Wiley- Liss. pp: 387-389.

FRYER JL, LANNON CN (1994) Three decades of fish cell culture: A current listing of cell lines derived from fishes. J. Tissue Cult. Methods 16: 87-94.

GRIMMETT SG, WARG JV, GETCHELL RG, JOHNSON DJ, BOWSER PR (2006) An unusual Koi Herpesvirus associated with a mortality event of common carp Cyprinus carpio in New York State, USA. J. Wild Life Diseases 42(3): 658-662.

HALABAN R, LANGDON R, BIRCHALL N, CUONO C, BAIRD A, SCOTT G, MOELLMAN G, MCGUIRE J (1988) Basic fibroblast growth factor from human keratinocytes is a natural mitogen for melanocytes. J Cell Biol 107:1611-1619.

HAM RG, MCKEEHAN WL (1979) Media and growth requirements. Methods in Enzymology 58: 44-93.
HEBERT PD N, CYWINSKA A, BALL SL, WAARD JRD (2003) Biological identifications through DNA barcodes. Proc. R. Soc., London B 270: 313-321.

HETRICK F.M, HEDRICK RP (1993) New Viruses described in finfish from 1988-1992. Annu Rev Fish Dis 3:187-207.

HONG Y, WINKLER C, SCHARTL M (1996) Pluripotency and differentiation of embryonic stem cell lines from the medakafish (Oryzias latipes). Mech Dev 60:33-44.

JENEY Z, JENEY G (1995) Recent achievements in studies on diseases of common carp (Cyprinus carpio L.). Aquaculture 129: 397-420.

JOSEPH, MA, SUSHMITHA RK, MOHAN CV, SHANKAR KM (1998) Evaluation of tissues of Indian major carps for development of cell lines by explant method. Curr. Sci 75:1403- 1406 .

LAI YS, JOHN JAC, LIN CH, GUO IC, CHEN SC, FANG K, LIN CH, CHANG CY (2003) Establishment of cell lines from a tropical grouper, Epinephelus awora and their susceptibility to grouper irido and nodaviruses. J. Fish Diseases 26:31-42.

LAKRA WS, BHONDE RR (1996) Development of primary cell culture from the caudal fin of an Indian major carp, Labeo rohita (Ham.). Asian Fisheries Science 9:149-152.

LAKRA W S, BHOINDE RR, SIVAKUMAR N, AYYAPPAN S (2006) A new fibroblast like cell line from the fry of golden masher Tor puttitora (Ham). Aquaculture. 253: 238-243.

LAKRA WS, SIVAKUMAR N, GOSWAMI M, BHONDE R (2006) Development of two cell culture systems from Asian seabass Lates calcarifer (Bloch). Aqua Research 37:18-24.

LAKRA WS, BEHERA MR, SIVAKUMAR N, GOSWAMI M, BHONDE RR (2005) Development of cell culture from liver and kidney of Indian Major Carp Labeo rohita. Indian J. Fisheries 52(3):373-376

MOHAN CV, SHANKAR KM (1994) Role of fungus in epizootic ulcerative syndrome of fresh and brackishwater fishes of Karnataka, India. Curr Sci 66:656-658.

KUMAR GS, SINGH IBS, PHILIP R (2001) Development of a cell culture system fromthe ovarian tissue of African cat- fish (Clarias gariepinus). Aquaculture. 194: 51-62.

OHNO S, MURAMOTO J, CHRISTIAN L, ATKIN B (1967) Diploidtetraploid relationship among Old World members of the fish family Cyprinidae. Chromosoma (Berl.) 23:1-9.

OIE (2006) Diagnostic Manual for Aquatic Animal Diseases, $3^{\text {rd }}$ ed. Office International des Epizooties, World Organisation for Animal Health, Paris, pp:237, http://www.oie.int/eng/normes/fmanual/ A_summry.htm.

PALUMBI S, MARTIN A, ROMANO S, MCMILLAN WO, STICE L, GRABOWSKI G (1991) The simple fool's guide to PCR. Version2.0. Honolulu, HL 96822: Department of Zoology and Kewalo Marine Laboratory, University of Hawaii.

PARAMESWARAN V, SHUKLA R, BHONDE RR, HAMEED ASS (2006) Splenic cell line from sea bass, Lates calcerifer: Establishment and characterization. Aquaculture 261:43-53.

PARAMESWARAN V, AHMED VPI, SHUKLA R, BHONDE RR, HAMEED ASS (2007) PRASANNA I, LAKRA WS, OGALE SN, BHONDE RR (2000) Development and characterization of two new cell lines from milkfish (Chanos chanos) and grouper (Epinephelus coioides) for virus isolation Mar. Biotechnol. 9:281-291

RAO KS, JOSEPH M.A, SHANKER K.M, MOHAN CV (1997) Primary cell culture from explants of heart tissue of Indian Major carps. Curr. Sci. 73: $374-375$

RATHORE G, SOOD N, SWAMINATHAN TR (2001) Primary Cell Culture from Clarias garenpinus fish gills and kidney using fish serum. Indian J. Exp. Biol. 39: 936-938.

RUZZANTE DE, TAGGART CT, COOK C, GODDARD S (1996) Genetic differentiation between inshore and offshore Atlantic cod (Gadus morhua) off Newfoundland: microsatellite DNA variation and antifreeze level. Can J Fish Aquat Sci 53: 634-645.

SATHE PS, MAURYA DT, BASU A, GOGATE SS, BANERJEE K (1995) Establishment and characterization of a new fish cell line, MG-3, from the gills of Mrigal Cirrhinus mrigala. Indian J Exp Biol 33:589-594.

SINGH I.S.B., ROSAMMA P., RAVEENDRANATHM. \& SHANMUGAM J. (1995) Development of primary cell cultures from kidney of freshwater fish Heteropneustes fossilis. Indian J Exp Biol 33:595-599.

SUN L, BRADFORD CS, GHOSH C, COLLODI P, BARNES DW (1995) ESlike cell cultures derived from early zebrafish embryos. Mol Mar Biol Biotechnol 4:193-199.

TONG SL, LI H, MIAO HZ (1997) The establishment and partial characterization of a continuous fish cell line FG- 9307 from the gill of flounder. Paralichthys olivaceus. Aquaculture 156:327-333. 
WAKAMATSU, Y, OIKAWA A, OBIKA M, HIROBE T, OZATO K (1984) Fish hereditary melanoma cell lines of different degrees of cell differentiation. Development Growth and Differentiation 25: 503-513.

WARD RD, ZEMLAK TS, INNES BH, LAST PR, HEBERT PDN (2005) DNA barcoding Australia's fish species. Proc. R. Soc., London B 360: 1847-1857.

WEYTS FAA, ROMBOUT JHWM, FLIK G, VERBURG-VANKEMENADE
BM L (1997) A common carp leucocyte cell line (Cyprinus carpioL.) shares morphological and functional characteristics with macrophages. Fish \& Shellfish Immunology 7(2):123-133.

YE, HQ, CHEN S L, SHA Z X, XU, MY (2006) Development and characterization of cell lines from heart, liver, spleen and head kidney of sea perch Lateolabrax japonicus. J. Fish Biol. 69 (Supplement A): $115-126$ 